\title{
Why Compassionate Release? A Follow-up to "What is Compassionate Release?" \\ Timothy Muise
}

My article "What Is Compassionate Release?" appeared in Volume 122(2) of the Journal of Prisoners on Prisons (Muise, 2013). I did my best to describe what the compassionate medical release of prisoners is and how it has become what I feel is one of the most pressing topics in penology. In this follow-up article, I emphasize the urgency for the medical release of prisoners, as it is clear that the wheels of justice and humanity have spun for far too long on this topic.

In the summer of 2000 the New England Journal on Criminal and Civil Confinement ran a piece by Nadine Curran (2000) which, in Nostradamuslike fashion, laid out the future of elderly prison populations and landscape of corrections yet to come if this dilemma of aging prison demographics is not aggressively addressed. Her piece, "Blue Hairs in the Big House: The Rise in Elderly Inmate Population", should have been the harbinger of change, at a bare minimum started a discussion about plans for change, but sadly her stark warnings went unheeded. As a result, we are in the midst of a true crisis in the form of the aging prisoner populations and the negative impact it has on the daily quality of life for the American taxpayer cannot be discounted.

For decades, the estimated costs of housing elderly prisoners have been three times the cost of housing prisoners under 50 years of age (Sutton, 1983). These astronomical costs are driving state corrections budgets through the roof. In Massachusetts, medical care takes up 18.52 percent of the total yearly corrections budget, ringing in at about $\$ 95$ million (Massachusetts Department of Correction, 2011). The added security costs of housing dying prisoners, coupled with the complicated medical care that must be afforded the chronic conditions this population faces, makes caring for these 'Big House Blue Hairs' untenable. Many of the individual case-studies show the elderly prisoner no longer poses any threat to society, making security unnecessary. However, in corrections security comes first as this need is what employs guards. The tail wags the dog.

The detrimental effects of housing aging prisoners are not always discussed, but are just as traumatizing to public safety as are the financial costs. Tough on crime policies, such as more widespread use of life without parole sentences, fuels prison overcrowding (Turner et al., 1995). Such overcrowding is a great concern due to the fact that it so negatively impacts 
rehabilitation, as well as the health and safety of prisoners and prison employees. Physical, spiritual and mental health are all negatively impacted by prison overcrowding (Gottfredson, 1984). Many times the end result of such overcrowding and the hopelessness of life sentences is an increased suicide rate (Rosenblat, 1991). The state of Massachusetts, which has no compassionate / medical release, proves this when in 2010 Massachusetts rose to number one in per capita prison suicide rate (Hayes, 2007). As a result, the Norfolk Lifers Group, of which I was a member of the board of directors at the time, met with Massachusetts Undersecretary for Criminal Justice, Sandra McCroom, and then Commissioner of Corrections Harold Clarke, who both expressed at that meeting that overcrowding was thought to play a role in suicides in Massachusetts. I personally presented the case for compassionate release to then Commissioner Clarke, but he was unreceptive. His proposed solution was to build another maximum-security prison - typical corrections-minded thinking. While Mr. Clarke no longer works in Massachusetts, the dilemma of the aging prisoner, their social costs, is still ours here in the Commonwealth.

The greater number of prisoners in any facility results in greater delays in receiving services, whether rehabilitative or medical (Ornduff, 1993). The American Medical Association (AMA) has also found that long term housing in overcrowded conditions accelerates heart conditions and high blood pressure (Rosenblatt, 1991), again increasing medical costs. The AMA also found that the psychological effects of prison overcrowding decreases the immune system (ibid). When you create an environment that is so unproductive to rehabilitation, you endanger the very public that corrections was created to protect. Increasing prison populations ensure jobs for corrections employees but diminish the quality of life for citizens who demand that public safety efforts actually make them safer (Procunier v. Martinez, 1974). Overcrowding breeds hopelessness and this is the key element for recidivism.

There are also legal ramifications to housing old and dying prisoners in an overcrowded and abusive prison environment. Elderly prisoners become prey to younger and stronger prisoners. This wolf-prey concept constitutes cruel and unusual punishment (Kelsey, 1986), as does housing them in overcrowded and services stressed conditions (Ornduff, 1993). The United States Constitution not only guards against "torture and other barbarous 
methods of punishment", as clarified by the United States Supreme Court, but also demands and protects, "broad and idealistic concepts of dignity, civilized standards, humanity, and decency" (Ornduff, 1993). To keep an elderly prisoner, who no longer poses any threat to society, in overcrowded, undignified and indecent conditions of confinement is actionable under the law, but more deflating is that it is morally reprehensible. This once proud nation must hang its head in shame as we have placed prison/law enforcement complex before compassion, humanity and decency. The time is long overdue for the United States of America to be the shining beacon of justice tempered with mercy.

Both the judicial system and the legislature have powers to create and implement a viable system of compassionate release (Rosenblatt, 1991). An advisory board of licensed, accredited, and peer-reviewed professionals needs to be assembled to ascertain who would meet an objective set of criteria for immediate release to managed care facilities. The first direct savings financially would be the elimination of security costs. The direct social impact would be freeing-up services for prisoners seeking rehabilitation opportunities. The courts would have the power to issue early release orders if corrections and public safety officials are reluctant to abide by advisory board recommendations (ibid). If the legislature cannot pass law in the required time the urgency demands then the court system may be the only viable alternative. Once the legislative branch enacts law the judicial branch would ultimately be charged with enforcing it, but the House and Senate cannot pull themselves out of the political quagmire (they have been arguing medical release measures since 1993), ${ }^{1}$ the burden must fall upon a brave judicial system. Such courage has been rare here in Massachusetts, but public outcry would inject valour into the circulation of those wearing the robes. The gavel must bang for solutions.

Our society can no longer afford this massive criminal justice bureaucracy that has created the "prison industrial complex" (Schlosser, 1998). The focus must be placed back on rehabilitation and proven crime reducing programming and education. Learning is the cure for crime and compassion surely the elixir for all that ails the system.

Two organizations here in the Commonwealth of Massachusetts are working to make compassionate medical release a reality here in the state. To find out how you can get involved, please contact: 


$\begin{array}{ll}\text { Holly Barnoski } & \text { Karen Schulman } \\ \text { Secretary } & \text { Secretary } \\ \text { CURE-ARM, Inc. } & \text { BREAD and WATER PRISONERS } \\ \text { PO Box 396 } & \text { PO Box 84 } \\ \text { Billerica, MA } & \text { Hopedale, MA } \\ 01821 & 01747 \\ \text { Tmuise63@gmail.com } & \text { KLSchulman@verizon.net } \\ \text { facebook.com/curearminc } & \text { facebook.com/BreadandWaterPrisoners }\end{array}$

Both groups would love to hear your thoughts, ideas, commentary and support. Why compassionate release? Our humanity and dignity demands it.

\section{ENDNOTES}

1 See the Massachusetts House Resolution \#4149 (1993) and \#3699 (1997b).

\section{REFERENCES}

Carter, Derrick A. (2014) Reflections on Proposed Federal Crime Bill.

Curran, Nadine (2000) "Blue Hairs in the Big House: The Rise in Elderly Inmate Population Its Effects on the Overcrowding Dilemma and Solutions to Correct It", New England Journal on Criminal and Civil Confinement, 26(2): 225-264.

Gottfredson, Stephen D. (1984) "Institutional Responses to Prison Overcrowding", New York University Review of Law and Social Change, 12(1): 259-297.

Hayes, L. (2007) Technical Assistance Report on Suicide Prevention Practices within the Massachusetts Department of Corrections, Mansfield: National Center on Institutions and Alternatives.

Kelsey, O.W. (1986) "Elderly Inmates: Provide Safe and Humane Care", Corrections Today, 48: 56, 58.

Massachusetts Department of Correction (2011) Annual Report. Available at http:// www.mass.gov/eopss/docs/doc/annual-report-2011-final-08-01-12.pdf.

Muise, Timothy J. (2013) "What is Compassionate Release?", Journal of Prisoners on Prison, 22(2): 46-49.

Ornduff, Jason S. (1993) "Releasing the Elderly Inmate: A Solution to Prison Overcrowding", The Elder Law Journal, 4: 173-200.

Procunier v. Martinez, 416 U.S. 396, 94 S.Ct. 1800 (1974).

Rosenblat, Pamela M. (1991) "The Dilemma of Overcrowding in the Nation's Prisons", New York Law School Journal of Human Rights, 8(2): 489-522

Schlosser, Eric (1998) "The Prison Industrial Complex", The Atlantic. Available at http://www.theatlantic.com/magazine/archive/1998/12/the-prison-industrialcomplex/304669/ 
Sutton, Christine (1983) Crime and Delinquency, Lanham (MD): Lexington Books.

Turner, Michael G., Jody L. Sundt, B. K. Applegate and K.T. Cullen (1995) "Three Strikes and You're Out Legislation: A National Assessment”, Federal Probation, 59: 16-35. 